\title{
The Role of the External in Local Peacebuilding: Enabling Action-Managing Risk
} (i)

\author{
Jannie Lilja and Kristine Höglund
}

\begin{abstract}
Local peacebuilding has been embraced in principle by many donors, but the practice of external support to local initiatives needs further systematic study. While previous research has exposed the weaknesses of externally supported peacebuilding, less attention has been given to alternative strategies that can be taken to scale. This article puts the focus on international nongovernmental organizations as key intermediary actors in peacebuilding, and how they deal with dilemmas attached to local peacebuilding support. It contributes to the research on external-local dimensions of peacebuilding practice by identifying constructive functions that can be fulfilled by INGOs in situations where local institutions and actors are not able to address conflict on their own. Specifically, it uncovers the role of INGOs as risk absorbers and enablers of local peacebuilding action through the accompaniment of local partners. KEYWORDS: peacebuilding, local, external.
\end{abstract}

THERE IS A COMPELLING CASE TO BE MADE FOR LOCAL PEACEBUILDING. The track record of the international community in consolidating peace is mixed, and the number of armed conflicts is increasing. Critics of the liberal peacebuilding framework have exposed the weaknesses of externally supported peacebuilding, and point to the many successful local peacebuilding efforts that tend to go unnoticed by the outside world. Yet there are situations where local institutions, structures, and actors are unable to constructively deal with issues of conflict alone. In the realm of international peacebuilding, there is a growing realization that external efforts need to be locally anchored if they are to promote peace: key policy and development actors stress the importance of local ownership, inclusivity, local capacity building, and community-driven initiatives. ${ }^{1}$ Whereas efforts are evolving and the principles of local peacebuilding have been embraced by many peacebuilding actors, there still is a vast disconnect between small-scale local peacebuilding efforts and the large-scale external presence in conflict-prone states as well as a failure to articulate clear alternative strategies that can be taken to scale. ${ }^{2}$ Given this, there is a need for further systematic study of how local peacebuilding can be externally supported: by what actors, the approaches used, and the strategies employed. To address this research gap, we use insights from contemporary peacebuilding practice and

(C) Jannie Lilja and Kristine Höglund, 2018

This is an open access article distributed under the terms of the prevailing CC-BY-NC-ND license at the time of publication. 
focus on how international nongovernmental organizations (INGOs) engage and interact with local partners. In external efforts to support local peacebuilding, INGOs are highly relevant to explore since they serve as a key connector between the international policy and donor community on the one hand, and local peace initiatives on the other hand. More specifically, we map practices and approaches to deal with the dilemmas of local peacebuilding as employed by five well-established INGOs with significant track records: Interpeace, Life and Peace Institute (LPI), Women's International League for Peace and Freedom (WILPF), Centre for the Democratic Control of the Armed Forces (DCAF), and an anonymous faith-based organization (FBO). By probing how these organizations address the challenges of external-local engagement, we are able to identify the functions INGOs may fill — and the mechanisms at play-in externally supported peacebuilding efforts. The analysis rests primarily on interviews with representatives of these organizations, and thus provides a limited, but important, step in understanding the dynamics of externally supported peacebuilding.

This article contributes to the growing research agenda on the local turn in peacebuilding, by advancing knowledge of how external actors seek to constructively address the challenges that mark external-local dynamics. ${ }^{3}$ In doing so, we address both a theoretical and a policy gap. A large share of the research advocating local peacebuilding is critical in nature and attempts to identify problems associated with international peacebuilding such as impediments for local ownership and the lack of contextually adapted approaches. ${ }^{4}$ Only a few studies have explored in detail how INGOs engage with local peacebuilding actors at the operational level, including issues of partner selection and control over decisions and resource allocations. ${ }^{5}$ Our study adds to this literature by identifying key functions fulfilled by INGOs in supporting local peacebuilding during circumstances where local actors are not able to address conflict by themselves. Whereas previous research has identified and analyzed INGOs as important third parties that facilitate dialogue and negotiations between local actors to address the conflict divide, ${ }^{6}$ this article highlights the functions of INGOs as a key connector between donors and local peacebuilders.

Our analysis reveals how INGOs can play two important functions in the support of local peacebuilding: as risk absorbers and as accompanying actors who can enable local agency in a more sustained fashion. Today's well-regulated aid flows, involving strong financial and managerial requirements placed on bilateral and multilateral donors, shift the risk taking to intermediaries - INGOs - that are able to engage with not yet so institutionalized and managerial local peacebuilding actors in relatively volatile settings. Moreover, in line with research on peacebuilding, aid effectiveness, and the determinants of nongovernmental organization (NGO) funding, this analysis highlights how incentive structures facing INGOs, including time frames for funding and constraints on partner selection, shape their interaction with local partners. In particular, through an accompani- 
ment approach and by separating the financial relationship and partner relation, a longer-term, more sustained, engagement can be made possible. ${ }^{7}$

\section{External Support to Local Peacebuilding}

Peacebuilding can be defined as a wide range of activities aimed at social, political, and institutional transformation required to create a lasting and self-sustaining peace. ${ }^{8}$ Key components are often described as reforms of the political, justice, and security sectors, coupled with socioeconomic development. Peacebuilding may also be viewed in terms of the impact of specific activities. ${ }^{9}$

There is a large literature on peacebuilding. A key debate has centered on the rift between liberal peacebuilding and more communitarian visions of peacebuilding. ${ }^{10}$ The liberal peace is viewed as efforts to "bring war shattered societies into conformity with the international system's prevailing standards of domestic governance." 11 Often described as top down, the liberal perspective holds that global norms exist and should be allowed to influence. A critical theory critique of the vertical dimension underpinning many peacebuilding interventions rests on the logic that international notions of peace, and measurements of peace, risk becoming irrelevant to local communities in being too aggregated, too broad, too narrow, or in other ways deficient. ${ }^{12}$ Peacebuilding should instead aim at being transformative. From this perspective peace can be achieved when communities begin to move beyond "negative imaginaries," engage in dialogue across social divides, and through everyday interaction shape the form of peace that may be either very much in tune, or out of tune with elite projections of peace. $^{13}$

Lacking a common understanding of what the local consists of, research on local peacebuilding has moved toward a more disaggregated and nuanced meaning of the term. From such a perspective, the local consists of networks, relationships, and activities - as opposed to a unitary actor linked to a specific territory. ${ }^{14}$ The local is also not the same as subnational, but may transcend the borders of nation states as in cases of diaspora activity. ${ }^{15}$ It is clear that local actors tend to be more diverse and divided than unitary. They may range from central government to local government, to non-state armed groups, to women's civil society organizations, religious networks, and labor unions. ${ }^{16}$

The literature on local peacebuilding puts an increasing focus on the interaction between internationals and locals via concepts such as the hybridity of peacebuilding and friction between local and international actors. ${ }^{17}$ Research in this realm questions the dichotomy that sets up the international as empowered actors "doing the peacebuilding and the disempowered local beneficiaries for whom the intervention is done." 18 Instead, important work seeks to conceptualize and adapt peacebuilding activities for local circumstances. ${ }^{19}$ Moreover, research also uncovers how - when peacebuilding involves internationals - outcomes are coproduced in the interaction between local and international actors, sometimes 
for the benefit of peace, and sometimes with detrimental effects for longer-term peace, development, and democracy.

So, do external actors have a role to play at all in supporting peace? While the absence and inactivity of external actors may allow local actors to be key players in peacebuilding, our point of departure is that there are situations where local institutions, structures, and actors are either too weak or lack the legitimacy necessary to address conflict. Such situations may arise due to conflict dynamics, or may be the very reason why the conflict began in the first place. In short, there are sometimes limits to internal peacemaking. ${ }^{20} \mathrm{~A}$ typical situation for when external support may be needed is when security sector reform is required to move a peace process forward, but when civilian trust in existing security structures is limited as a result of conflict. In such cases, the local parties face commitment problems and the provision of third-party security guarantees is one way to overcome deepseated mistrust. ${ }^{21}$ Indeed, local leadership and ownership can be problematic when local actors are not committed to peace. Local indigenous practices may in fact contribute to reproducing social inequalities and injustices, rather than changing the status quo. ${ }^{22}$

\section{The International Peacebuilding Chain: External-Local Dynamics}

Peacebuilding can come about in multiple ways and, when externally supported, it can trickle down to the local level through different channels. External actors engaged in local peacebuilding are not a uniform crowd and include a wide range of more or less organized actors: multilateral and bilateral donors, peacekeepers, diplomats, regional actors, international civil society, international religious movements, international business, and academia. The worldviews, norms, and practices of external peacebuilders will influence the peacebuilding approach and who they choose to engage with. For this reason, the identity of the international peacebuilder matters. Severine Autesserre argues that there are critical differences between international actors in terms of their engagement with local actors, in the acceptance to risk, and in the ability to understand the local dynamics of conflict. ${ }^{23}$ These variations contribute to shaping both interventions and peacebuilding outcomes.

This study focuses on peacebuilding efforts involving INGOs as intermediary actors in external efforts to promote local peacebuiling. These INGOs form a critical link in a chain of actors that ranges from external donor headquarters to local groups and indivduals.

Simplified, as illustrated in Figure 1, the chain consists of external headquarters actors - multilateral organizations and donor governments. They in turn provide financing to international nongovernmental organizations that fulfill requisite policy and financial management requirements. The INGOs identify partners, local NGOs or other forms of organized local civil society, with whom they interact. Local NGOs or civil society on their part directly cooperate with local individuals and groups. In this article, a local $N G O$ refers to an $\mathrm{NGO}$ operating at national 
Figure 1 International Peacebuilding Chain: From Externals to Locals

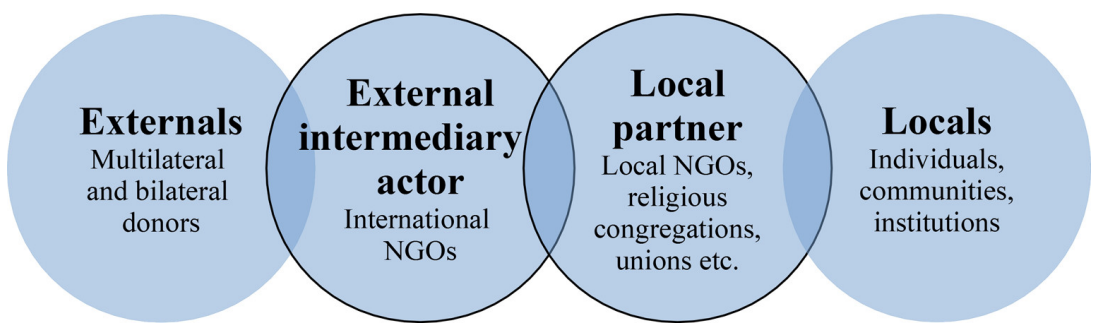

or subnational levels, or both. Organized civil society could be, for instance, church congregations, religious networks, or unions, which are not NGOs in the formal sense. The INGOs may also work directly with local individuals; for example, in conflict resolution efforts. However, it is local NGOs that stand for the large frequency and breadth of interaction with stakeholders at the local level.

\section{External Challenges in Local Peacebuilding Support}

International nongovernmental organizations select and work with local partners and may thereby have significant leverage over issues related to local ownership and control over decisionmaking. Yet there are numerous challenges to why a local peacebuilding approach is difficult for outsiders to apply. Many of them are rooted in institutional barriers to interaction..$^{24}$ External actors' concern with their own or their partner's security may hamper local-external engagement. ${ }^{25}$

Theoretically, this article revolves around three main challenges identified by previous research as being of particular relevance for INGOs engaging in local peacebuilding. First, the question of representation may be difficult to solve: who should be represented, prioritized, and given voice. ${ }^{26}$ International peacebuilders tend to prefer partnering with moderates and internationally oriented local partners, which may not be those who are most significant for peace. Connected to this issue is how external actors manage situations when the priorities of select locals are at odds with basic international norms. ${ }^{27}$ As highlighted in the literature on friction and peacebuilding, such contestation may either cause adverse effects on the progression to peace, or have emancipatory effects. ${ }^{28}$

These issues are also connected to the pitfalls and scale of external funding. It is a dilemma for donors that grassroots-based and locally anchored civil society with the most potential to promote the desired change does not always meet the organizational or financial requirements of "professionalism and accountability" demanded by donors..$^{29}$ Financing may pacify forces for social change, referred to as the NGO-ization of social movements. ${ }^{30}$ Foreign funding may also crowd out the genuinely committed local actors. For these reasons, some suggest that external funding be used with care, and that a slow pace in the scale-up and focus on organic growth be allowed. ${ }^{31}$ 
Second, there is the issue of local ownership over priorities and finances. Ownership in local peacebuilding is determined by the level of control that locals exercise over the process and outcome. ${ }^{32}$ Carolyn Hayman differentiates between initiatives that are (1) locally led, where locals design the approach and set priorities while outsiders assist with resources; (2) locally owned, where the approach comes from the outside, but is "transplanted" to local ownership; or (3) locally delivered, primarily an outside approach, including external priorities that locals are supposed to implement. ${ }^{33}$ The type of local control is also linked to the identity of the local actor, ranging from the government executive, to parliament, civil society, the security sector, and all the way to vulnerable communities and groups. The literature on participatory and community approaches to development and humanitarian work suggest that beneficiaries are often supposed to do what the externals have already decided, as opposed to setting their own agendas. ${ }^{34}$

Third, time frames and timing is another challenge for externally supported local peacebuilding. Inherently, peacebuilding takes time. Yet longer time horizons are not always consistent with project or program time cycles of those who support local peacebuilding from the outside. ${ }^{35}$ Local actors may also have various incentives for speeding up reconstruction. These may be of an economic nature. But there could also be incentives for local elites to not produce results. Victims' concerns for postwar justice or reconciliation may have repercussions for local elites implicated in past atrocities. However, if conflict issues are left unaddressed, the risk of relapse remains.

\section{How INGOs as External Intermediaries Engage with the Local}

We explore how international nongovernmental organizations as mediating actors operationally engage with locals in support of local peace initiatives by identifying and comparing practices that five INGOs - Interpeace, Life and Peace Institute, Women's International League for Peace and Freedom, Centre for the Democratic Control of the Armed Forces, and an anonymous faith-based organization - employ to constructively deal with the three main dilemmas outlined above. These organizations have their headquarters in Europe, and are funded primarily by bilateral donors. Most of them have a presence in Africa. They are working with local actors in places such as Somalia, Democratic Republic of Congo, Burundi, Syria, and Iraq.

These organizations have been engaged for a long time in the broader realm of peacebuilding, ranging from 15 to 100 years. All are well established, and they are regarded as central peacebuilding INGOs by many donors and observers. For instance, LPI has a long-standing reputation based on its bottom-up approach to peacebuilding. ${ }^{36}$ WILPF, the oldest international women's peace organization, is considered to be one of the leading INGOs pioneering gender-informed peacebuilding. ${ }^{37}$ Interpeace's sustained peacebuilding facilitation, for example in Somalia, is also recognized. ${ }^{38}$ 
We deliberately chose organizations that are diverse in terms of their specific orientation. Three name themselves as "peacebuilding" organizations outright. The fourth works on security sector reform, here seen as a subset of peacebuilding. The fifth, a faith-based organization, does not explicitly brand itself as a peacebuilding organization, but has a pronounced focus on local ownership for development, which entails peacebuilding work. The inclusion of this organization is expected to further illustrate some of the trade-offs between the "local" and "peacebuilding."

Our analysis draws on interviews with one key representative of each organization and written accounts of the organizations' approaches to local peacebuilding. ${ }^{39}$ The interviews were conducted in English and carried out by the lead author. The interviewees were informed about the purpose of the study and gave their informed consent to use the interview material for academic research purposes. The empirical material, thus, largely consists of self-reported accounts of how these organizations approach peacebuilding. The empirics do not consider actual impact as this would require a much larger assessment of causality, attribution, and local context. Yet this one-sided approach provides a first and necessary step in exploring how INGOs address local peacebuilding dilemmas.

We structure our empirical exploration around three important challenges identified by previous research on local peacebuilding: (1) representationfocusing on the selection and recruitment of local partners; (2) degree of local control over decisionmaking and funding; and (3) time horizons. Before embarking on how the INGOs address these problems, we describe how the organizations conceptualize peacebuilding to understand how they view their core area of work.

\section{Conceptualizations of Peacebuilding}

There is no general agreement on what peacebuilding entails in practice. Indeed, peacebuilding may not only be the labeling of activities, which may vary significantly among different peacebuilding actors and funders, but also the very end goal of activities. The INGOs in this study conceptualize peacebuilding in a rather all-encompassing way by including broader nonviolence and pro-justice efforts. The promotion of nonviolence, or "regulated, accountable violence," is an objective that cuts across all the organizations. More specific aims for peacebuilding are: the strengthening of society's ability to manage conflict nonviolently through inclusive political processes; ${ }^{40}$ challenging militarized approaches to addressing conflict; ${ }^{41}$ strengthening security sector accountability and reform; ${ }^{42}$ supporting marginalized and vulnerable people in voicing their needs and concerns; ${ }^{43}$ and strengthening civil society's ability to build peace and sustain dialogue. ${ }^{44}$

Examples of peacebuilding activities are the setting up and support of inclusive peace and reform processes; facilitating the creation of peace movements or networks; building up the capacity of local peace partners through training and mentoring; and pro-peace advocacy and lobbying. These activities are carried out 
to deal with conflict issues revolving around, for example, access to land, natural resource distribution, or the prevention of child recruitment. ${ }^{45}$

Several of the organizations emphasize the need for joint external-local peacebuilding analysis. ${ }^{46}$ LPI uses participatory action research as a method to help local partners define their own priorities. However, that also necessitates that LPI conduct a meta-analysis of what constitutes peacebuilding. Some pure livelihood projects, for instance, have not qualified as peacebuilding. WILPF includes a pronounced feminist perspective, which narrows or broadens the scope of the peacebuilding analysis, depending on how one views it. The faith-based organization in the past has not been very direct with regard to the types of activities undertaken by local partners. ${ }^{47}$

The INGOs point to the difficulty of measuring results of peacebuilding activities. The mere creation of a space between conflicting groups for the exchange of views and dialogue is "not a measurable structure - not even a process," according to DCAF. Thus, the formulation of local peacebuilding priorities, and longer-term thinking of how to link local level efforts to central decisionmaking structures, may constitute nonconventional outputs, according to DCAF. ${ }^{48}$

Some INGOs do not view the promotion of peace as being confined to armed conflict settings. Interpeace, which works in places such as Somalia, Guatemala, and Côte d' Ivoire, has also recently started peacebuilding projects in a suburb of Stockholm, Sweden. Also, in the words of a WILPF representative, "We are a cause-based movement - a peace organization. We are not in the game of 'developing someone' and then leave. One of our main focuses is on prevention. In fact, our European sections are very strong." 49

In sum, the analysis of how INGOs conceptualize peacebuilding suggests that peacebuilding takes on different meanings for the various organizations although nonviolence, violence reduction, and justice figure as key objectives. All INGOs stress the importance of the steps toward peacebuilding, or "peacebuilding as process." Most of them operate by some preset notion or metatheory of peacebuilding and, therefore, are able to distinguish what falls outside of the scope.

\section{Representation: Selection of Local Partners}

The process of selecting or recruiting local partners is an important component of the external-local dynamics in peacebuilding. It surfaces as a critical element for the INGOs. Considerable time and effort is invested in actor mapping and analysis - coupled with various rounds of verification. According to the INGOs explored here, a process of active selection can take from four months to two years.

Most of the INGOs initially carry out some sort of network analysis. They look for local actors that can exert an impact, by attempting to identify trustworthy and influential local partners. ${ }^{50}$ The local actors' alignments and political positions, along with their capability and ability to influence, enter the calculation 
of whether or how the INGO chooses to engage. The INGOs try to understand where the partner is situated in relation to the dividing lines of conflict. ${ }^{51}$ The size of the prospective local partner's networks may enter into the assessment. ${ }^{52}$ Local partners may extend into the informal sphere, including militias, rebel groups, traditional leaders, and academics..$^{53}$

"Values checking" is part of the selection process for three of the organizations. ${ }^{54}$ The INGOs would seek answers to questions such as: Is the local partner progressive in terms of norms and values? Does the local partner take a rights-based approach ${ }^{55}$ Is the prospective local partner "doing the right thing" in relation to conflict causes and dynamics? ${ }^{56}$ The organizations that do not explicitly mention values checking instead stress the peacebuilding impact. This includes being trustworthy in the eyes of the opponent, ${ }^{57}$ or playing a significant role in security provision. ${ }^{58}$

Interpeace uses an intricate and active selection procedure, as explained by its director general:

A process of change needs to be led by consensus figures in that society. To find these individuals, we would first go to the formal power holders. To the president, but also to the head of the opposition or rebel groups, to understand how they view conflict and how to get out of the situation. We would ask the president whom he or she would trust to lead a process of true reconciliation? The president would list a number of people. Then we would ask-which of these names would your enemies also trust? Then we would go to the opposition leader and ask the same question. It is an iterative process where you are constantly re-checking names. Ultimately, even in a divided society, you will find a couple of individuals that everyone can trust. What is key is integrity. We do not know who these individuals are from the beginning. ${ }^{59}$

In this case, scouting is made for individuals with high integrity who are trusted across the lines of conflict. Trustworthiness in the eyes of the opponent is what matters. "We do not presuppose who these people are." ${ }^{60}$ Trust is also key when it comes to the relationship between the INGO and the local partner.

The programmatic, financial, and administrative capacities and systems of partners are evaluated by the INGOs that provide funding. A prehistory of collaboration may help to reduce the fears and insecurities involved in working on sensitive peacebuilding topics in a high-risk environment. The selection of local partner may, in other words, be an unintended outcome of past collaboration on a less touchy subject. ${ }^{61}$

Recommendations from other INGOs play into the selection. However, an "accompaniment approach" taken by some of the INGOs tends to involve the gradual buildup of locals' capacity through training and other forms of capacity building. ${ }^{62}$ "There are obstacles to local engagement that we as outsiders create. Most donors want a 3-year track record. A local organization in the Central African 
Republic or Somalia would simply lack that," Interpeace reports. ${ }^{63}$ "Our accompaniment approach allows us to work with partners that are not as established." 64 The introduction of funding often gives rise to significant compliance restrictions. Beyond anticorruption requirements, antiterrorism provisions introduced by the host government may also narrow the set of possible local counterparts. ${ }^{65}$

The INGOs target different kinds of local partners depending on the restrictions set by their own mandates. Two organizations scout for individuals at the national level who are powerholders or agents of change. ${ }^{66}$ The three other organizations have a more limited scope when it comes to selecting partners and collaborate primarily with civilian actors. ${ }^{67}$ Local partner selection may also be strategically linked to the overarching themes that the INGO intends to work on. ${ }^{68}$

For the representative of an anonymous FBO, however, the local partners are very much given: "We do not choose our partners." Some partnerships date back almost 100 years and are interwoven with deep personal connections linked to church congregations in the INGO host country. There is often a high level of trust in these relationships, but no deliberate partner selection. Instead, host country congregations do the scouting for local partners. However, a program started by a local church counterpart may subsequently be turned into a separate independent local NGO instead. ${ }^{69}$

To summarize, when selecting local partners, the INGOs look for partners with peace impact potential. However, the organizations differ in that some primarily scout for locals that match their values and adhere to a human rightsbased approach whereas others primarily look for locals with conflict resolution capacity. As a result, they select different kinds of local counterparts. The former approach will yield largely civilian partners whereas the latter could imply that militants or militaries are approached as well.

\section{Local Ownership over Priorities and Finances}

Questions related to ownership constitute a critical dimension of the externallocal relationship in peacebuilding, including issues related to priorities and to financing. How do the INGOs structure their relations with local partners when it comes to decisionmaking on priorities and financing?

All the INGOs reported that they jointly formulate priorities with their local partners - although to different degrees. There is no complete carte blanche when it comes to local control over decisions on priorities. LPI grants a relatively high level of local control by using participatory action research (PAR), a participatory process to identify drivers of conflict and ways to deal with them. ${ }^{70}$ The PAR phase typically spans over six months. However, LPI still conducts independent conflict analysis to weed out local proposals that are not seen as promoting peacebuilding. Similarly, the very process of prioritization is seen as part of the peacebuilding work by Interpeace. The local partners are viewed as facilitators of an internal process of peace rather than the "owners." 
The highest degree of delegated authority is with the faith-based organization, which historically has adhered to goals set by local partners-after the latter have passed an assessment, which involves requisite organizational capacity and financial structures. This reflects the mandate of the organization, which compared to the others is broader and more focused on development and poverty eradication. ${ }^{72}$ Consequently, not all of its activities are peacebuilding in nature.

When it comes to control over funds, there is a distinction between the INGOs that fund local partners and those that do not. Those that provide actual funding enter into detailed contractual relationships, underpinned by, for instance, financial assessment requirements. Another financial aspect related to local ownership is that co-financing between an INGO and its local NGO counterpart may be conceived of as a manifest signal of local ownership, reflecting that the local counterpart sees the issue as a priority. ${ }^{73}$ The INGOs may also work with local partners without providing any funding. In these cases, the INGO may offer training, advice, mentoring, advocacy, and lobbying support, and facilitate the creation of policy-related networks of local actors. "Donors think it is just about channeling money. It is not. It is too early. They [the local organizations] will just break down. So we put a lot of focus on capacity development," says the Interpeace director general. ${ }^{74}$

Unless local partners have robust financial systems and evaluation capacities, they will have difficulties in accessing donor funds. For this reason, the faith-based organization encourages local partners to form separate NGOs, and even put this as a requirement for operations in one country. To form a local NGO, the INGO initially provides financial capacity building support. When the local partner is assessed as being robust from a financial and managerial perspective, the INGO serves as a guarantor that the local partner will be able to handle the funding obtained in line with requirements. The local partner then largely gets to decide on the direction of financial allocations. ${ }^{75}$

A Memorandum of Understanding (MOU) between an INGO and its local partners can play a key role in regulating the external-local relationship by setting the balance of control and responsibility. The more money involved, the more detailed is the MOU. Specifically, according to LPI,

The MOU outlines the length of relationship, our expectations (for us and them), the type of partnership, along with anti corruption and financial management commitments. Our MOU have evolved and gotten longer. Different donors have different restrictions and guidelines. There are different types of MOUs. Some are open ended, while some are specifically tied to an activity or project. Some are for our institutional partners and some are just for our project partners. ${ }^{76}$

The INGOs speak of an "accompaniment approach," marked by close and continuous interaction between the INGOs and their local partners, by decisions made jointly, and by locals being capacitated: "We are in this together 
and we accompany them quite intensely." 77 The approach may manifest itself in participatory action research to support locals in coming up with peacebuilding priorities, ${ }^{78}$ but may also consist of advise, training, and capacity building, including support to build up financial systems. ${ }^{79}$ LPI's executive director describes how they "use an accompaniment for an organization that does not meet the requirements" 80 while Interpeace reports that what they "focus on early is the build up of their institutional capabilities from a financing and administrative point of view. If they are to be credible politically, they have to be credible financially." 81

In conclusion, when INGOs are involved, there are no entirely locally led initiatives. Instead, joint control over priorities and finances are reportedly used. The INGOs that provide funding, or aim at providing funding to locals, take an accompaniment approach whereby they follow and mentor the work of local partners in their process of gradually building up financial and substantive capacity.

\section{Time Horizons}

A final dimension of importance for external-local relations concerns time horizons. Peacebuilding takes time and the length of the external engagement matters. How do INGOs manage issues related to the duration of engagement?

Most of the organizations are interested in establishing long-term partnerships with local actors, but make a distinction between relationships and funding. "When it comes to relationships, we want them [the local partners] to be forever. When it comes to funding, they [the local partners] should be sustainable and not go on forever," the representative of an anonymous FBO says. Interpeace reasons in terms of medium- to long-term investments, where long is about ten to fifteen years: "We don't let them go," says the Interpeace director general. ${ }^{82}$ DCAF states that they "are not interested in doing ad hoc, one-off things." 83 However, for LPI, it is important to formulate an end state from the beginning for when a partner has built enough capacity to get support from other donors. ${ }^{84}$

There may be a delicate trade-off between developing a long-term bond of mutual trust between externals and locals, and the need by INGOs to disengage for funding or policy reasons. One organization pinpoints the need to manage local expectations, and to have an honest conversation about what it as an outsider can and cannot do. If resources fluctuate, that can create fragility. However, there have been instances of longer-term engagement such as a Dutch governmentsupported eight-year program in Burundi in which DCAF was involved. Yet electoral cycles may make it difficult for donor governments to commit to such long-term horizons.

Exit strategies may be more or less clear. "Once a partnership has been established, it can be difficult to change regardless of the priorities. Thus in some cases we have chosen not to engage with some specific partners, but have preferred to build broader alliances to focus on strategic processes," the WILPF representa- 
tive states. The external-local relationship may also be ended ahead of time due to changes in local leadership, personal or institutional egos, or for reasons of financial mismanagement. ${ }^{85}$ Although the funding relationship with a particular partner may be terminated, the partnership as such may live on ${ }^{86}$ In the case of the faith-based organization, the ending of a financial partnership may be further diffused or even reversed as host country congregations may raise their own money through charity to keep funding the local partner. ${ }^{87}$

To summarize, peacebuilding actors operate in a high-risk environment, and it takes time to develop trust between INGOs and local partners. In addition, the peacebuilding tasks of promoting nonviolence, justice, and accountability require a sustained long-term effort. Yet, funding cycles and the expectation for results may be significantly shorter. Some INGOs resolve this by separating the partnership and the funding relationship. However, strategic thinking about exit strategies varies between the organizations.

\section{Main Insights on INGO Strategies and Functions}

This article focuses on how international nongovernmental organizations promote local peacebuilding as external intermediaries in the chain of interaction between the international and the local spheres. The INGOs analyzed interface with bilateral and multilateral donors on the one hand, and with local actors on the other hand. While the INGOs constitute a subset of actors involved in peacebuilding, and the analysis represents the organizations' own perspectives of their role as connectors, our analysis offers several important insights.

First, partnership selection is a critical, but time-consuming and highly demanding task for INGOs. The process of assessing prospective local partners based on possible peacebuilding impact proves quite meticulous and involves both practical and normative considerations. For INGOs involved in local peacebuilding, issues innate to the very peacebuilding context, such as antiterrorism provisions, could significantly restrict the sample of potential local partners. Moreover, the values checking that some INGOs use in partner selection may similarly preclude certain local counterparts due to normative concerns, suggesting a trade-off between a rights-based and conflict resolution approach.

Second, by separating the shorter-term financial relationship from the longerterm partner relationship with local peacebuilders, sustained external engagement can be made possible. From previous research, we know that financial accountability and external donor funding cycles may shorten time frames, direct activities in ways not conducive to peacebuilding, and projectify longer processes of change. Our findings show that a separation between the shorter-term financial relationship and the longer-term partnership with local actors allows external actors to become engaged before the local partner is ready for financial support, and to remain engaged after financing ends through the sharing of knowledge and expertise and training. The adverse impact of funding can thus be overcome. 
Based on the approaches employed by the INGOs, two main functions of external INGO support to local peacebuilding can be inferred. The first function concerns risk. Peacemaking necessitates risk taking. Local peacebuilders often face risks at a personal level; for instance, in terms of physical security or economic subsistence if the work is considered sensitive. Donors may confront fiduciary risks of engaging with local partners that do not have organizational capacity to administer funds, which does not allow tracking of, or accounting for, taxpayers' money. Donors could also face political risk due to restricted mandates and host country agreements.

INGOs can contribute to local peacebuilding by playing the role of risk managers or risk absorbers financially and politically. INGOs help donors and local partners to increase knowledge, and acquire a certain degree of protection and insurance, in line with previous research. ${ }^{88}$ When it comes to funding, the literature has shown that managerial and professional civil society organizations are more likely to receive financial support than those with strong local ties. ${ }^{89}$ Thus, the intermediary function performed by the INGOs allows multilateral and bilateral aid to be channeled to local peacebuilders. Using the private sector as an illustration, the INGOs - in trying to identify and invest in local peace agentscould be seen as risk capitalists involved in company incubation and startup. The multilateral and bilateral donors prefer to provide operational financing to already established and relatively mature medium- to large-sized "peace" enterprises. This can be problematic in a changing high-risk environment marked by informality and "peace actors in the making." Through screening and capacitation, INGOs step in to fill this function of a frontline risk buffer. The cases suggest instances of local actors that initially had an INGO as their only external partner, but that subsequently received direct funding from donors with more extensive requirements. Yet complete reliance on international funding, as opposed to local sources, may create vulnerabilities in cases of crackdown on foreign-funded organizations..$^{90}$

The INGOs can also help to absorb political risk associated with direct engagement with civilian opposition, or non-state armed groups. Donors may be constrained by their own mandates or by multiple principals wanting to steer action in opposite directions. Both bilateral and multilateral actors may have developed organizational routines that hamper the necessary flexibility for when, how, and with whom to engage locally. ${ }^{91}$ The INGOs may be able to act expeditiously and interface more freely with the non-state side, which is essential in internal armed conflicts.

The second function concerns INGOs' accompaniment role, which can enable and sustain local action over time by strengthening local organizations and capacities for peace. While local society hosts a wealth of capacity, may stand for local legitimacy, and is best suited to identify the core local needs for peacebuilding, previous research has shown that in societies where civil society or political opposition has been banned for a long time or where a tradition of 
participatory politics is missing, local capacity on how to formulate policy and pursue advocacy may be weak. In such cases, externals can also enable local partners to engage in more targeted and strategic action and communication. Local organizations may themselves have to take on the role of facilitators of a domestic peacebuilding process that is co-owned by many local stakeholders. To structure dialogue processes, they may get process support from INGOs, which serve more of a background role as indirect facilitators. The existing literature also shows that managerial capacity and ability to craft proposals that fulfill the requirements of funders are key determinants for accessing donor resources. ${ }^{92}$ Thus, local knowledge and know-how may need to be complemented with capacity to make a local organization amenable for external funding.

The accompaniment approach, with its focus on strengthening local agency in a more sustained way, can be seen as a response to the call by Timothy Donais for longer-term international engagement with local actors. Accompaniment is more process than outcome oriented, and signals a more equal relationship between external actors and local partners. ${ }^{93}$

\section{Implications for Future Research and Policy}

Two issues raised by this analysis warrant further research. First, insights on the intermediary functions played by INGO local peacebuilding support relate to recent discussions on organizational ecology in international relations. ${ }^{94}$ Organizational ecology is a structural theory stressing the organizational environments where organizations operate in terms of organizational density and resource availability. It highlights constraints and opportunities that institutional environments create. In the context of external peacebuilding assistance, it is important for future research to probe further into how financial restrictions, predictability, and accountability frameworks that multilateral and bilateral actors attach to aid could reduce necessary risk taking overall, and transfer the risk taking necessary for peacebuilding from multilateral and bilateral actors to INGOs. Questions of the appropriate sharing of risk between local peacebuilders, intermediary INGOs, and donors across the international peacebuilding chain should be addressed more systematically.

Second, more research is needed on the impact that different INGO strategies and the approaches identified here have on various forms of local peacebuilding, and on perception of local ownership. In fact, local co-leadership seems to be more prevalent than local leadership as such. Through an accompaniment approach, the INGO can facilitate and advise local actors on the actual process of coming up with priorities. From this perspective, the very notion of local ownership needs to be further problematized.

Our analysis does not presume that external support is decisive, or at all sufficient, to bring about lasting peace. While the INGOs in our study reported both normative and practical considerations in partner selection, a larger sample 
would enable an analysis of how different procedures of, and concerns for, partner selection influence the type of local actors that get prominent roles in local peacebuilding. In the context of a war-to-peace transition, it is also questionable if one or a few local organizations really can own peacebuilding priorities. In essence, to fully understand how the external-local interaction can be improved, more research is required on how local populations and local counterpart organizations perceive of issues such as partner selection criteria, and the usefulness of particular forms of outside support, for strengthening their ability to build peace.

\section{Notes}

Jannie Lilja is an associate researcher with the Department of Peace and Conflict Research, Uppsala University. Her areas of expertise cover peacebuilding, human security, development, human rights, negotiations, and the dynamics of war and peace processes. Kristine Höglund is professor at the Department of Peace and Conflict Research, Uppsala University. Her areas of expertise include the causes and consequences of electoral violence, and the dynamics of peace processes, peacebuilding, and transitional justice. She is coeditor of Understanding Peace Research: Methods and Challenges (2011, with Magnus Öberg) and Peacebuilding and Friction: Global and Local Encounters in Post-Conflict Societies (2016, with Annika Björkdahl et al.).

Lilja is the lead author of this article. Höglund primarily worked on the theory and analysis.

The authors would like to thank the interviewees for contributing to the study, and Isak Svensson and Johanna Söderström for excellent comments on drafts of the article. Lilja is grateful to Carolyn Hayman for providing early inspiration for this article. Höglund acknowledges funding support from the Swedish Research Council.

1. Timothy Donais and Erin McCandless, "International Peace Building and the Emerging Inclusivity Norm," Third World Quarterly 30, no. 2 (2017): 291-310.

2. Alvaro de Soto and Graciana Del Castillo, "Obstacles to Peacebuilding Revisited," Global Governance 22, no. 2 (2016): 209-227.

3. For example, Caroline Hughes, Joakim Öjendahl, and Isabell Schiernbeck, "The Struggle Versus the Song-The Local Turn in Peacebuilding," Third World Quarterly 36, no. 5 (2015): 817-824; Roger Mac Ginty and Oliver Richmond, "The Local Turn in Peacebuilding: A Critical Agenda for Peace," Third World Quarterly 34, no. 5 (2013): 763-783.

4. For example, Severine Autesserre, Peaceland (Cambridge: Cambridge University Press, 2014); Susanna Campbell, Global Governance and Local Peace (Cambridge: Cambridge University Press, forthcoming); Anna Jarstad and Roberto Belloni, "Introducing Hybrid Peace Governance," Global Governance 18, no. 1 (2012): 1-6; Annika Björkdahl, Kristine Höglund, Gearoid Millar, Jair Van der Lijn, and Willemijn Verkoren, eds., Peacebuilding and Friction: Global and Local Encounters in Post-conflict Societies (London: Routledge, 2016), Oliver Richmond, The Transformation of Peace (Basingstoke: Palgrave, 2005).

5. Roberto Belloni, "Civil Society in War-to-Democracy Transitions," in Anna 
Jarstad and Timothy Sisk, eds., From War to Democracy: Dilemmas of Peacebuilding (Cambridge: Cambridge University Press, 2012), pp. 182-210; Timothy Donais, Peacebuilding and Local Ownership: Post-conflict Consensus Building (London: Routledge, 2012); Anna Jarstad and Louise Olsson, "Hybrid Peace Ownership in Afghanistan," Global Governance 18, no. 1 (2012): 105-119; Willemijn Verkoren and Mathijs van Leeuwen, "The Imagined Agent of Peace," in Annika Björkdahl, Kristine Höglund, Gearoid Millar, Jair Van der Lijn, and Willemijn Verkoren, eds., Peacebuilding and Friction: Global and Local Encounters in Post-conflict Societies (London: Routledge, 2016): pp. 103-119.

6. For example, Jacob Bercovitch and Richard Jackson, Conflict Resolution in the Twenty-first Century (Ann Arbor: University of Michigan Press, 2009), pp. 137-150; Nathan Shea, "Nongovernment Organisations as Mediators," Global Change, Peace \& Security 28, no. 2 (2016): 177-196.

7. See, for example, François Bourguignon and Mark Sundberg, "Aid Effectiveness," American Economic Review 97, no. 2 (2007): 316-321; Lisa Chauvet and Paul Collier, "Development Effectiveness in Fragile States" (Oxford: Centre for the Study of African Economies, Oxford University, January 2004); Alexander Cooley and James Ron, "The NGO Scramble,"International Security 27, no. 1 (2002): 5-39; David Suarez and Mary Kay Gugerty, “Funding Civil Society?” Voluntas 27, no. 6 (2016): 2617-2640.

8. Eva Bertram, "Reinventing Governments: The Promise and Perils of United Nations Peace Building," Journal of Conflict Resolution 39, no. 3 (1995): 387-418; Anna Jarstad and Timothy Sisk, eds., From War to Democracy: Dilemmas of Peacebuilding (Cambridge: Cambridge University Press, 2008).

9. Donais, Peacebuilding and Local Ownership.

10. Ibid.

11. Roland Paris, "International Peacebuilding and the 'Mission Civilisatrice,'” Review of International Studies 28, no. 4 (2002): 638.

12. Roger Mac Ginty, "Indicators +: A Proposal for Everyday Peace Indicators," Evaluation and Program Planning 36, no. 1 (2013): 56-63; Roger Mac Ginty, "Where Is the Local? Critical Localism and Peacebuilding," Third World Quarterly 36, no. 5 (2015): $840-856$.

13. Mac Ginty, “Where Is the Local?” pp. 850-852.

14. Ibid.

15. Kristine Höglund and Camilla Orjuela, "Friction and the Pursuit of Justice in Post-war Sri Lanka," Peacebuilding 1, no. 3 (2013): 300-316.

16. Tania Paffenholz, "Civil Society," in Roger Mac Ginty, ed., Routledge Handbook of Peacebuilding (London: Routledge, 2013): 347-359.

17. Autesserre, Peaceland; Donais, Peacebuilding and Local Ownership, p. 142; Diana Felix da Costa and John Karlsrud, "Contextualising Liberal Peacebuilding for Local Circumstances," Journal of Peacebuilding and Development 7, no. 2 (2013): 53-66.

18. Björkdahl, Höglund, Millar, Van der Lijn, and Verkoren, Peacebuilding and Friction, p. 2.

19. Felix da Costa and Karlsrud, "Contextualising Liberal Peacebuilding for Local Circumstances."

20. Jannie Lilja and Mohamed Manga, "Going It Alone: The Casamance Conflict and the Challenges of Internal Peace Making," in Mikael Eriksson and Roland Kostic, eds., Mediation and Liberal Peacebuilding (London: Routledge, 2013): 118-132. 
21. Laurie Nathan, No Ownership, No Commitment: A Guide to Local Ownership of Security Sector Reform (Birmingham: University of Birmingham, 2007); Barbara Walter, Committing to Peace: The Successful Settlement of Civil Wars (Princeton: Princeton University Press, 2002).

22. Anthony Wanis-St. John, "Indigenous Peacebuilding," in Roger Mac Ginty, ed., Routledge Handbook of Peacebuilding (London: Routledge, 2013): 360-374.

23. Autesserre, Peaceland.

24. Susanna Campbell, "Routine Learning? How Peacebuilding Organizations Prevent Liberal Peace," in Susanna Campbell, David Chandler, and Meera Sabaratnam, eds., A Liberal Peace? The Problems and Practices of Peacebuilding (London: Zed Books, 2011): 89-105; Campbell, Global Governance and Local Peace.

25. Autesserre, Peaceland.

26. Cedric de Coning, "Understanding Peacebuilding as Essentially Local," Stability 2, no. 1 (2013): 1-6; Donais, Peacebuilding and Local Ownership, p. 9.

27. Donais, Peacebuilding and Local Ownership, p. 9.

28. Björkdahl, Höglund, Millar, Van der Lijn, and Verkoren, Peacebuilding and Friction.

29. Verkoren and van Leeuwen, "The Imagined Agent of Peace."

30. Camilla Orjuela, Civil Society in Civil War (Göteborg: Göteborg University, 2004).

31. Carolyn Hayman, "Local First in Peacebuilding," Peace Review 25, no. 1 (2013): $17-23$.

32. Donais, Peacebuilding and Local Ownership; Jarstad and Olsson, "Hybrid Peace Ownership in Afghanistan"; Hayman, "Local First in Peacebuilding"; Mac Ginty and Richmond, "The Local Turn in Peacebuilding."

33. Hayman, "Local First in Peacebuilding," p. 18.

34. Elisabeth Olivius, “(Un)Governable Subjects,” Journal of Refugee Studies 27, no. 1 (2013): 42-61; Elizabeth Holzer, The Concerned Women of Buduburam: Refugee Activists and Humanitarian Dilemmas (Ithaca: Cornell University Press, 2015).

35. Donais, Peacebuilding and Local Ownership, pp. 8-16; Campbell, "Routine Learning?"

36. Severine Autesserre, The Trouble with the Congo (Cambridge: Cambridge University Press, 2010), pp. 188, 211.

37. Eleanor O'Gorman, “Independent Thematic Review on Gender for the UN Peacebuilding Support Office” (New York: UN Peacebuilding Support Office, 2014), p. 62.

38. For example, Meagan Allen and Cate Broussard, Working in the Nexus of Peacebuilding and Democracy Building (Washington, DC: School of International Service, American University, 2013); Emma Leonard and Gilbert Ramsay, Globalizing Somalia: Multilateral, International and Transnational Repercussions of Conflict (New York: Bloomsbury, 2013).

39. Interpeace, "Toolkit Manual: For the Implementation of the Interpeace Approach in Mali and Côte d' Ivoire" (Geneva: Interpeace, 2016); Ornella Moderan, "Tool 1Political Leadership and National Ownership of SSR Processes" (Geneva: Centre for the Democratic Control of the Armed Forces [DCAF], 2015); "LPI's Planning, Monitoring, Evaluation and Learning Tool" (Uppsala: Life and Peace Institute [LPI], 2011).

40. Scott Weber, director-general of Interpeace, interviewed by the first author, Geneva, 27 August 2015. 
41. Barbro Svedberg, programme director of the Women's International League for Peace and Freedom (WILPF), interviewed by the first author, Geneva, 1 April 2016.

42. Mark Downes, assistant director, head of the International Security Sector Advisory Team, Geneva Centre for the Democratic Control of Armed Forces (DCAF), interviewed by the first author, Geneva, 8 January 2016.

43. Representative of anonymous FBO, interviewed by the first author, Stockholm, 2 April 2016.

44. Judy McCallum, executive director of the Life and Peace Institute (LPI), interviewed by the first author, Uppsala, 6 April 2016.

45. McCallum interview; Svedberg interview; Weber interview.

46. Weber interview; Svedberg interview; McCallum interview.

47. Representative of anonymous FBO interview.

48. Downes interview; DCAF, "Managing for Results: DCAF Performance Report 2016," 2017, www.dcaf.ch/sites/default/files/imce/About-Dcaf/DCAF -PERFORMANCE-REPORT-2016.pdf.

49. Svedberg interview; WILPF, “Annual Report 2016: Women's International League for Peace and Freedom," https://wilpf.org/wp-content/uploads/2017/10/WILPF -Annual-Report_2016_web.pdf, 2017.

50. Weber interview.

51. Downes interview; McCallum interview.

52. Svedberg interview.

53. Weber interview; Downes interview.

54. Svedberg interview; representative of anonymous FBO interview; McCallum interview.

55. Representative of anonymous FBO interview.

56. McCallum interview.

57. Weber interview.

58. Downes interview.

59. Weber interview; Pruitt Bettye and Philip Thomas, Democratic Dialogue-A Handbook for Practitioners (New York: UNDP, 2007), describes Interpeace's approach, pp. 57-58, 55, 32, www.undp.org/content/dam/undp/library/crisis\%20prevention /democratic\%20_dialogue.pdf.

60. Weber interview.

61. Downes interview.

62. Weber interview; representative of anonymous FBO interview; McCallum interview.

63. Weber interview; Jennifer Milliken, What the Peacebuilding Community Can Contribute to Political Transitions in North Africa and Beyond, Geneva Peacebuilding Platform Paper No. 4, p. 7, http:/gpplatform.ch/sites/default/files/GPP\%20Annual\%20Report $\% 202011 \% 20-\% 20$ Peacebuilding\%20and\%20Political\%20Transitions.pdf.

64. Representative of anonymous FBO interview.

65. McCallum interview.

66. Weber interview; Downes interview.

67. Svedberg interview; representative of anonymous FBO interview; McCallum interview.

68. McCallum interview. 
69. Representative of anonymous FBO interview.

70. McCallum interview.

71. Weber interview.

72. Representative of anonymous FBO interview.

73. Downes interview.

74. Weber interview; Interpeace, Pillars of Peace: Somali Programme-Challenges and Opportunities in the Central Regions (Geneva: Interpeace, 2012), www.interpeace .org/wp-content/uploads/2012/08/2012_08_28_SomSC_Pillars_Of_Peace_ENG.pdf.

75. Representative of anonymous FBO interview. The guarantee would be made in relation to the INGO's bilateral donor.

76. McCallum interview.

77. Weber interview.

78. McCallum interview.

79. Weber interview; representative of anonymous FBO interview; McCallum interview.

80. McCallum interview.

81. Weber interview.

82. Weber interview.

83. Downes interview.

84. McCallum interview; Finn Skadkaer Pedersen, Andre Kahlmeyer, Pontus Modéer, Evaluation of the Life and Peace Institute: LPI Final Report (Stockholm: Sida, 2012), p. 69, https://www.sida.se/contentassets/975650408a9148bbbb142220f3a53d8d/ evaluation-of-the-life-and-peace-institute-8211-lpi-final-report_3294.pdf.

85 . Weber interview; representative of anonymous FBO interview; McCallum interview.

86. Representative of anonymous FBO interview.

87. Ibid.

88. Isaac Ehrlich and Gary Becker, "Market Insurance, Self-insurance and Selfprotection," Journal of Political Economy 80, no. 4 (1972): 623-648.

89. Suarez and Gugerty, "Funding Civil Society?"

90. Kendra Dupuy, James Ron, and Aseem Prakash, "Who Survived? Ethiopia's Regulatory Crackdown on Foreign-funded NGOs," Review of International Political Economy 22, no. 2 (2015): 419-456; James Ron, Archana Pandya, and David Crow, "Universal Values, Foreign Money," Review of International Political Economy 23, no. 1 (2016): 129-164.

91. Campbell, "Routine Learning?"

92. Suarez and Gugerty, "Funding Civil Society?"; Lise Philipsen, "Escaping Friction," in Annika Björkdahl, Kristine Höglund, Gearoid Millar, Jair Van der Lijn, and Willemijn Verkoren, eds., Peacebuilding and Friction: Global and Local Encounters in Post-conflict Societies (London: Routledge, 2016), pp. 64-83.

93. Donais, Peacebuilding and Local Ownership.

94. Kenneth Abbott, Jessica Green, and Robert Keohane, “Organizational Ecology and Institutional Change in Global Governance," International Organization 70, no. 2 (2016): 1-31. 